\title{
Cloning and expression of Toxoplasma gondii GRA-4 recombinant protein as a toxoplasmosis diagnostic kit candidate
}

\author{
Muhammad Hanafiah ${ }^{1}$, Teuku Zahrial HelmiiD, Amalia Sutriana ${ }^{3}$ (D), Dwi Priyowidodo ${ }^{(D)}$ and Fihiruddin Fihiruddin ${ }^{5}$ (iD \\ 1. Parasitology Laboratory, Faculty of Veterinary Medicine, Universitas Syiah Kuala, Banda Aceh, Indonesia; 2. Laboratory \\ of Biochemistry, Faculty of Veterinary Medicine, Universitas Syiah Kuala, Banda Aceh, Indonesia; 3. Pharmacology \\ Laboratory, Faculty of Veterinary Medicine, Universitas Syiah Kuala Banda Aceh, Indonesia; 4. Department of \\ Parasitology, Faculty of Veterinary Medicine, Gadjah Mada University, Yogyakarta, Indonesia; 5. Department of Medical \\ Laboratory Technology, Politeknik Kemenkes Mataram, Sandubaya Mataram Nusa Tenggara Barat Indonesia. \\ Corresponding author: Muhammad Hanafiah, e-mail: hanafi_2015@unsyiah.ac.id \\ Co-authors: TZH: zahrial_fkh@unsyiah.ac.id, AS: amalia_sutriana@unsyiah.ac.id, DP: priyo@ugm.ac.id, \\ FF: fihir.analis@yahoo.co.id
}

Received: 31-03-2020, Accepted: 24-08-2020, Published online: 05-10-2020

doi: www.doi.org/10.14202/vetworld.2020.2085-2091 How to cite this article: Hanafiah M, Helmi TZ, Sutriana A, Priyowidodo D, Fihiruddin F (2020) Cloning and expression of Toxoplasma gondii GRA-4 recombinant protein as a toxoplasmosis diagnostic kit candidate, Veterinary World, 13(10): 2085-2091.

\begin{abstract}
Aim: The objective of this study was to produce recombinant protein GRA-4 (rGRA-4) of a local Toxoplasma gondii isolate as a candidate for a toxoplasmosis diagnosis kit in Escherichia coli BL21 (DE3) competent cells using pET SUMO plasmid.

Materials and Methods: Samples used were stock T. gondii tachyzoites DNA from the Parasitology Laboratory, Faculty of Veterinary Medicine, Gadjah Mada University, Yogyakarta. Amplified GRA-4 polymerase chain reaction product of $T$. gondii tachyzoite DNA was cloned in the pET-SUMO TA ${ }^{\mathrm{R}}$ cloning vector. The GRA-4 gene from T. gondii local isolate was sequenced, followed by plasmid transformation, recombinant plasmid DNA isolation, and recombinant protein expression in DE3 competent cells.

Results: The amplification product of GRA-4 T. gondii gene was $1036 \mathrm{bp}$, with $48 \mathrm{kDa}$ molecular weight after expression in DE3 competent cells. An alignment of the amino acid sequence of GRA-4 from the local isolate which was cloned with GRA-4 was obtained from NCBI database and showed $99.61 \%$ homology to the predicted GRA-4 from the T. gondii Izatnagar isolate. Amino acid sequence of the predicted GRA-4 protein from local isolate was different at positions 19 and 304.
\end{abstract}

Conclusion: This research cloned rGRA-4 in pET SUMO plasmid.

Keywords: cloning, expression, GRA-4, pET-SUMO, plasmid, recombinant.

\section{Introduction}

Toxoplasma gondii is a protozoan parasite that infects all mammals and birds and causes toxoplasmosis. The prevalence rate of $T$. gondii infection varies between countries, with infection rates between $10 \%$ and $80 \%$ of the population [1]. Moreover, animals consumed by humans are often infected with $T$. gondii muscle cysts, a source of parasite transmission to humans, which remain a public health concern [2]. Toxoplasmosis diagnosis consists of either a serological test using monoclonal antibody (fluorescent antibody, ELISA), polymerase chain reaction (PCR), molecular probes (DNA tracking), or dipstick test, in conjunction with clinical symptoms. Toxoplasma antigens have been detected in several domestic cat organs using immunohistochemistry with antigen labeled-(strept) Avidin-Biotin (LAB-SA) [3]. Hanafiah et al. [4] also detected $33.3 \%$ toxoplasmosis prevalence in cats using

Copyright: Hanafiah, et al. Open Access. This article is distributed under the terms of the Creative Commons Attribution 4.0 International License (http://creativecommons.org/licenses/ by/4.0/), which permits unrestricted use, distribution, and reproduction in any medium, provided you give appropriate credit to the original author(s) and the source, provide a link to the Creative Commons license, and indicate if changes were made. The Creative Commons Public Domain Dedication waiver (http:// creativecommons.org/publicdomain/zero/1.0/) applies to the data made available in this article, unless otherwise stated. the PCR technique. However, the use of recombinant GRA-4 (rGRA-4) protein as a potential antigen in a diagnostic kit has never been tested.

Toxoplasma diagnosis often uses antigens from research animals infected with $T$. gondii, but the method was recently banned due to animal welfare concerns [5]. As a solution, DNA recombinant technology can provide large amounts of immunogenic protein, allowing promising molecular based diagnostics and vaccine developments, and increasing feasibility and sustainability. The dense granule protein (GRA) is the main component of $T$. gondii vacuoles, which protect tachyzoites, the cyst wall, and bradyzoites, against the host humoral and cellular immune responses [6]. Recombinant antigen protein TgPI-1 (rTgPI-1), ROP2 (rROP2) and GRA-4 (rGRA-4) can easily be expressed and purified [7-9].

Here, the rROP2 (residues 96-561) and rGRA-4 proteins were expressed in Escherichia coli strain M15 (QIAGEN) and purified under non-denaturing condition on Ni2+-NTA agarose column, (QIAGEN), as described previously [7,10]. The objective of this research was to produce $T$. gondii recombinant antigen GRA-4 in E. coli BL21 (DE3) competent cells as a candidate for a toxoplasmosis vaccine and diagnostic kits. 


\section{Materials and Methods}

\section{Ethical approval}

This study was approved by Veterinary Ethics Committee Faculty of Veterinary Medicine Universitas Syiah Kuala, Banda Aceh, Indonesia (Approval No. 43/KEPH/IXVH/2019).

\section{Study location and period}

The research was performed in the Parasitology Laboratory, Faculty of Veterinary Medicine, Universitas Syiah Kuala and Inter-University Research Center, Gadjah Mada University (UGM), Yogyakarta, Indonesia. This study was conducted in April 2019.

\section{Amplification of $T$. gondii tachyzoite DNA by PCR}

DNA from $T$. gondii tachyzoites was obtained from the Parasitology Laboratory, Veterinary Medicine Faculty, UGM, Yogyakarta. The forward primer and reverse primers were designed according to $1036 \mathrm{bp}$ sequence obtained from GenBank (https://www.ncbi. nlm.nih.gov/genbank/), accession number M76432.1, utilizing the Gene Runner Software. Specific primers for the gene encoding the GRA-4 protein were forward primer GRA-4: 5'-ATG CAG GGC ACT TGG TTT TC-3' and reverse primer GRA-4: 5'-TCA CTC TTT GCG CAT TCT TT-3'. The primers were diluted to $10 \mathrm{pmol} / \mu \mathrm{L}$ concentration. The mixture for the amplification process was made by adding components into pure the Taq RTG-PCR as follows: $2 \mu \mathrm{L}$ template DNA, $2 \mu \mathrm{L}$ GRA-4 forward primer, and $2 \mu \mathrm{L}$ GRA-4 reverse primer, $12.5 \mu \mathrm{L}$ Taq polymerase (Biotaq $^{\circledR}$, Bioline, London, UK), and $6.5 \mu \mathrm{L}$ nuclease free water, to make a total volume of $25 \mu \mathrm{L}$.

Amplification utilized a thermocycler with the following settings: Denaturation at $94^{\circ} \mathrm{C}$ for $5 \mathrm{~min}$; annealing at $52^{\circ} \mathrm{C}$ for $40 \mathrm{~s}$, and extension at $72^{\circ} \mathrm{C}$ for $2 \mathrm{~min}$; followed by a final extension at $72^{\circ} \mathrm{C}$ for $5 \mathrm{~min}$, and cooling at $25^{\circ} \mathrm{C}$. All reactions were performed for 30 cycles. The amplification products were then processed for electrophoresis in 1\% agarose gel at 100 volts for $35 \mathrm{~min}$. Electrophoresis results were read using a transilluminator viewer.

\section{Nucleotide sequence of the T. gondii GRA-4 gene local isolate}

The resulting PCR product of the $T$. gondii GRA-4 gene was sequenced to compare the nucleotide sequences of the obtained gene with the $T$. gondii GRA-4 gene deposited in GenBank. Sequencing was also performed on the $G R A-4$ gene following insertion into pET SUMO plasmid sequence to confirm the correct position and frame. The Champion ${ }^{\mathrm{TM}} \mathrm{pET}$ SUMO Expression System was provided as a complete system. The Champion ${ }^{\mathrm{TM}}$ pET SUMO TA Cloning ${ }^{\circledR}$ box contains linearized Champion ${ }^{\mathrm{TM}}$ pET SUMO vector, sterile water, dNTPs, $10 \times$ PCR Buffer, control template and primers, T4 DNA ligase, 10× ligation buffer, primers for sequencing or PCR screening, and an expression control and stored at $-20^{\circ} \mathrm{C}$. The SUMO Protease box contains SUMO Protease and buffers and stored at $-80^{\circ} \mathrm{C}$. The One Shot $^{\circledR}$ TOP10 box contains 21
$50 \mu \mathrm{L}$ aliquots of chemically competent $E$. coli, SOC medium, and a control plasmid and stored at $-80^{\circ} \mathrm{C}$. The One Shot ${ }^{\circledR}$ BL21(DE3) box contains $2150 \mu \mathrm{L}$ aliquots of chemically competent $E$. coli, SOC medium, and a control plasmid and stored at $-80^{\circ} \mathrm{C}$. Sequencing was performed in the Integrated Research and Testing Laboratory, UGM, Yogyakarta.

\section{Cloning of the T. gondii GRA-4 gene in the pET-SUMO plasmid}

Fresh PCR product with a length of $1036 \mathrm{bp}$ was ligated to the pET-SUMO vector in the following ligation reaction: $2 \mu \mathrm{L}$ PCR product, $1 \mu \mathrm{L}$ ligation buffer, $2 \mu \mathrm{L}$ plasmid pET SUMO, $4 \mu \mathrm{L}$ nuclease free water, and $1 \mu \mathrm{L}$ of T4 DNA ligase (Invitrogen, Thermo Fischer, USA), in a total volume of $10 \mu \mathrm{L}$. The mixture was transferred into a microtube and incubated at $15^{\circ} \mathrm{C}$ for $4 \mathrm{~h}$ or overnight [11].

\section{Plasmid transformation}

To transform bacteria, $10 \mu \mathrm{L}$ of the cloning reaction was mixed with competent $E$. coli cells (One Short $^{\circledR}$ Mach1 ${ }^{\mathrm{TM}}-\mathrm{T} 1^{\mathrm{R}}$ Invitrogen, Thermo Fischer, USA) and incubated for $30 \mathrm{~min}$ on ice. Competent cells were heat-shocked for $30 \mathrm{~s}$ at $42^{\circ} \mathrm{C}$, and quickly placed on ice for 1-2 min, followed by the addition of $250 \mu \mathrm{L} \mathrm{SOC} \mathrm{medium.} \mathrm{The} \mathrm{tube} \mathrm{was} \mathrm{shaken} \mathrm{at} 200$ $\mathrm{rpm}$ at $37^{\circ} \mathrm{C}$ for $1 \mathrm{~h}$. The mixture was then plated on Luria Bertani (LB) agar, which contained $50 \mu \mathrm{g} / \mathrm{mL}$ kanamycin and incubated at $37^{\circ} \mathrm{C}$ for $24-48 \mathrm{~h}$.

\section{Recombinant plasmid DNA isolation}

Isolation of DNA plasmid was performed according the protocol provided in the Presto ${ }^{\mathrm{TM}}$ Mini Plasmid kit (Geneaid, New Taipei City, Taiwan).

\section{Amplification of T. gondii GRA-4 gene inserted from PET SUMO plasmid}

The amplification of T. gondii GRA-4 gene from the pET SUMO plasmid was performed using the GRA-4 forward and GRA-4 reverse specific primers and the plasmid SUMO forward and T7 reverse primers. T. gondii recombinant GRA-4 DNA was amplified by preparing a master mix solution of $25 \mu \mathrm{L}$ for each sample including $12.5 \mu \mathrm{L}$ of PCR master mix reaction solution, $2 \mu \mathrm{L}$ each of the GRA-4 forward and reverse primer, and along with $2 \mu \mathrm{L}$ of the SUMO forward primer and $2 \mu \mathrm{L}$ of the T7 reverse primer, at a concentration of $10 \mathrm{pmol} / \mu \mathrm{L}$ for each primer. The mixture included $6.5 \mu \mathrm{L}$ of $\mathrm{dH}_{2} 0$ and $2 \mu \mathrm{L}$ plasmid template.

The amplification process used a thermocycler with the following conditions: Initial denaturation at $94^{\circ} \mathrm{C}$ for $5 \mathrm{~min}$, denaturation at $94^{\circ} \mathrm{C}$ for $1 \mathrm{~min}$, annealing at $72^{\circ} \mathrm{C}$ for $1 \mathrm{~min}$, extension at $72^{\circ} \mathrm{C}$ for $1 \mathrm{~min}$, and final extension at $72^{\circ} \mathrm{C}$ for $5 \mathrm{~min}$, for 30 cycles.

\section{Recombinant protein expression}

Purified plasmid containing the T. gondii GRA-4 gene was then transferred into DE3 competent cells as described previously. The transformed bacteria were then cultured in $10.0 \mathrm{~mL}$ of liquid LB and incubated 
at $37^{\circ} \mathrm{C}$ for $24 \mathrm{~h}$. A total of $10 \%$ bacteria culture was transferred into liquid LB media and incubated for $4 \mathrm{~h}$ in a shaker $(180 \mathrm{rpm})$ until the culture reached 0.6 optical density. Into the culture, $1 \mathrm{mM}$ isopropyl $\beta$-d-1-thiogalactopyranoside was added and incubated for $2 \mathrm{~h}$. Induced cultured bacteria were transferred into two conical tubes $(50 \mathrm{~mL}$ each) and centrifuged $\left(4^{\circ} \mathrm{C}\right)$ at $5000 \mathrm{rpm}$ for $10 \mathrm{~min}$. The supernatant was discarded, and the pellet was resuspended, followed by dilution to $50 \mathrm{~mL}$. The diluted bacteria were then centrifuged $\left(4^{\circ} \mathrm{C}\right)$ at $5000 \mathrm{rpm}$ for $10 \mathrm{~min}$. The washing process was repeated twice. The supernatant was discarded and PBS I pH 7.0 was added into the pellet. The tube was sonicated 6 times for $30 \mathrm{~s}$. After sonication, a protein sample was added to a $1.5 \mathrm{~mL}$ tube. The microtube was centrifuged in a $4^{\circ} \mathrm{C}$ centrifuge at $10,000 \mathrm{rpm}$ for $5 \mathrm{~min}$. The resulting supernatant was transferred into a new tube, the protein was stored in $-20^{\circ} \mathrm{C}$ and the pellet was discarded.

\section{Purification and examination of protein using SDS-PAGE}

Preparation of $15 \%$ gradient gel and 3\% stacking gel was carried out for protein electrophoresis purpose. Gradient gel was allowed to flow to slab gel to a certain level and added with butanol to cover the surface of gradient gel solution. Polymerization of gradient gel occurs for 4-5 h, and then the gel surface was rinsed with aquadest to remove the remaining butanol. Gradient gel was overlaid with stacking gel, and the comb was inserted and left for 30-40 min. The loading dye was loaded to a protein sample with a ratio of $1: 4(10 \mu \mathrm{L}$ loading dye: $40 \mu \mathrm{L}$ sample) in a tube, homogenized, and heat the sample in boiling water at temperature of $-80^{\circ} \mathrm{C}$ for $5 \mathrm{~min}$. After heating, the sample was cooled, and then loaded in the gel wells of electrophoresis apparatus. The electrophoresis was run at $120 \mathrm{~V}$ for $2 \mathrm{~h}$ before stained with coomassie blue for $1 \mathrm{~h}$ using a shaker. The gel was rinsed with ddH2O, and then further washed using de-staining solution for $30 \mathrm{~min}$ until the clear bands were formed. Finally, the gel was rinsed with aquadest to remove the remaining color. Purification process was conducted using Nickel Affinity Gel Column Chromatography due to $\mathrm{Ag} 85$ is fusion protein consisting polyhistidine at N-terminal end. Procedure of purificaion was performed using protocol in Protino ${ }^{\mathrm{TM}} \mathrm{Ni}-\mathrm{TED} 2000$ which has been modified in elution volume.

\section{Results}

\section{Amplification of $T$. gondii tachyzoite DNA by PCR}

Genomic DNA of the local isolate of T. gondii tachyzoites was amplified by PCR and analyzed by agarose gel electrophoresis. The PCR product showed one band with a molecular weight of approximately 1038 bp (Figure-1).

\section{Nucleotide plasmid sequence and DNA recombinant}

Sequence analysis of the isolated GRA-4 gene was described previously [12] and sequence of the plasmid confirmed that there were no amplification errors in the cloned GRA-4 gene sequence. The sequence was also confirmed by comparing the database entry using the Basic Local Alignment Search Tool (BLAST) software.

After conducting BLAST runs for the predicted amino acid sequence using sequence deposited in GenBank, the sequence of GRA-4 gene from the local isolate showed homology with several T. gondii GRA-4 genes as presented in Table-1.

\section{GRA-4 protein clone in pET-SUMO plasmid}

The MUC I E. coli was successfully transformed with the GRA-4-containing pET SUMO plasmid and appeared as colonies on agar plates, as shown in Figure-2.

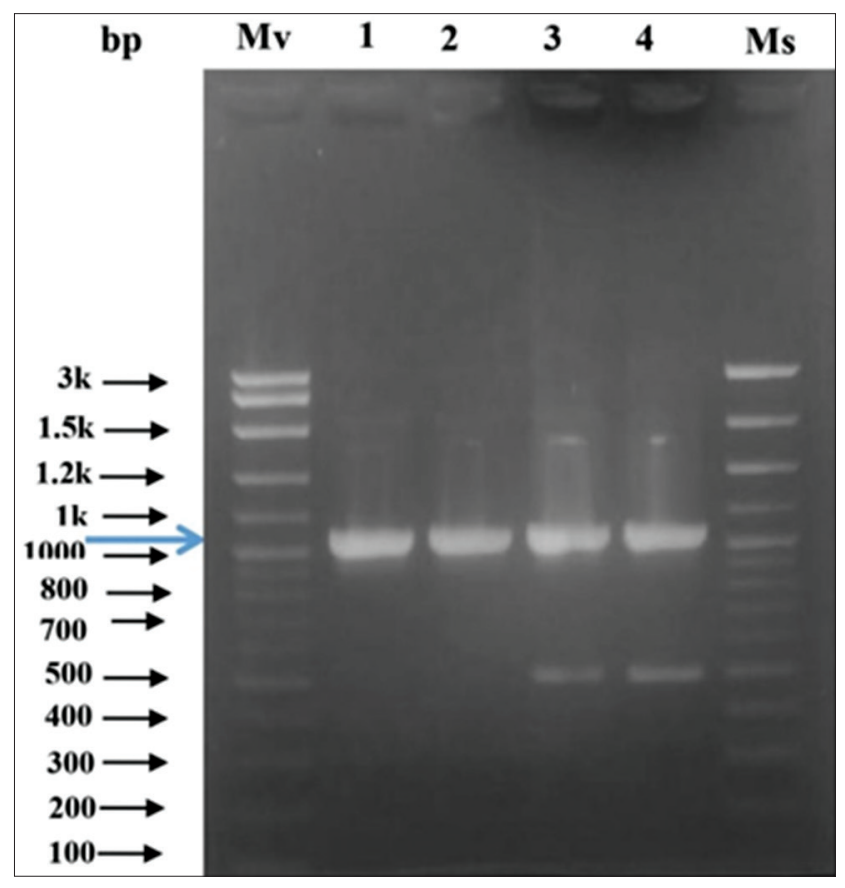

Figure-1: DNA amplification results from Toxoplasma GRA-4 gene in $1 \%$ agarose gel. $\mathrm{Mv}=$ Marker vivantis ( $1 \mathrm{~kb}$ DNA ladder); lane $1=$ DNA in $5 \times$ dilution (Mix Go Tag); lane $2=$ DNA in $10 \times$ dilution (Mix Go Tag); lane $3=$ DNA in $5 \times$ dilution (Bio line); lane $4=$ DNA in $10 \times$ dilution (Bio line); Ms=Marker smobio (1 kb DNA ladder).

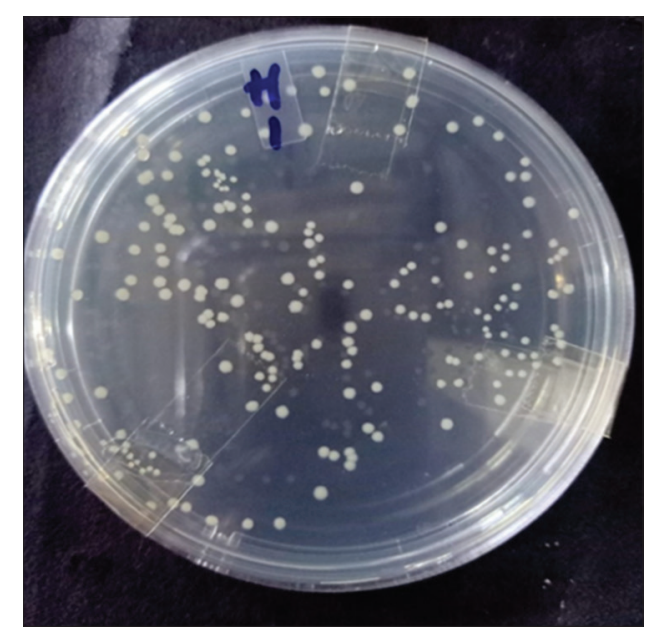

Figure-2: Bacterial colony of MUC I. 
Table-1: Homology of GRA-4 gene samples isolate with others Toxoplasma gondii in NCBI database.

\begin{tabular}{llccc}
\hline No. Bacteria species & Query (\%) & Coverage E. value & Identity (\%) & Accession \\
\hline $\begin{array}{l}\text { 1. gondii dense granule (GRA-4) gene, complete } \\
\text { cds }\end{array}$ & 100 & 0.00 & 100 & M76432.1 \\
2. $\quad$ T. gondii isolate Izatnagar GRA-4-like gene & 99 & 0.00 & 99.61 & EU660037.1 \\
3. $\quad \begin{array}{l}\text { TPA: } \text { T. gondii VEG, chromosome chrXI complete } \\
\quad \text { genome }\end{array}$ & 100 & 0.00 & 97.69 & LN714501.1 \\
4. gondii ME49 dense granule protein 4 (GRA-4) & 100 & 0.00 & 97.69 & XM 00236 \\
$\quad$ mRNA & & & 4283.1 \\
5. $\quad$ Tondii cDNA clone: XTG04280.2 full cDNA & 85 & 0.00 & 98.08 & AK317865.1 \\
\hline
\end{tabular}

T. gondii=Toxoplasma gondii

\section{Plasmid transformation}

Cultures of $E$. coli BL 21 transformed bacteria are shown in Figure-3.

\section{Recombinant plasmid DNA amplification}

Agarose gel electrophoresis of PCR products obtained from the recombinant plasmid DNA. Figure- 4 shows that the GRA-4 gene was a result of cloning inserted into pET SUMO vector. The used of pET SUMO vector as a cloning vector is controlled by bacteriophage T7 promotor. The target gene Ligation that is PCR product in pet sumo is conducted without using restrictions enzymes, since pET SUMO has 3' deoxythymidine (T) single residue which able to be directly inserted by PCR product into the multiple cloning site located between sumo and $\mathrm{T} 7$ terminator [13].

\section{Recombinant protein isolation}

The recombinant protein isolation product was then examined by SDS-Page. The results displayed the protein band with a size of $48 \mathrm{kDa}$ both in supernatant and protein pellet. Figure-5 shows the SDS page results of the recombinant GRA-4 protein.

\section{Discussion}

To produce $T$. gondii recombinant antigen, DNA from a tachyzoite sample was amplified using specific primers for GRA-4, which produced a 1038 bp product. The resulting DNA product was identical in size to the DNA amplified from the recombinant GRA-4 plasmid obtained from $E$. coli. These results show that GRA-4 gene was successfully cloned into the $\mathrm{pET}$ SUMO plasmid (Figure-1).

Gene cloning can routinely be performed using the PCR method, which allows a clone to carry a specific desired gene [14-16]. This study cloned the GRA-4 gene into the pET-SUMO (Figure-2) plasmid. Successful cloning using a PCR product is influenced by several factors: The purity of PCR product, the choice of restriction endonuclease enzyme, the creation of primer, and the choice of plasmid which is used as a PCR product carrier vector [17]. Although it has a low success rate, this cloning method has often been employed by adding restriction endonuclease enzyme into the primer mix, and using a relatively small plasmid vector $(2.9-5 \mathrm{~kb})$.

The T. gondii GRA-4 gene has been cloned previously by Marjanh et al. [18], who successfully

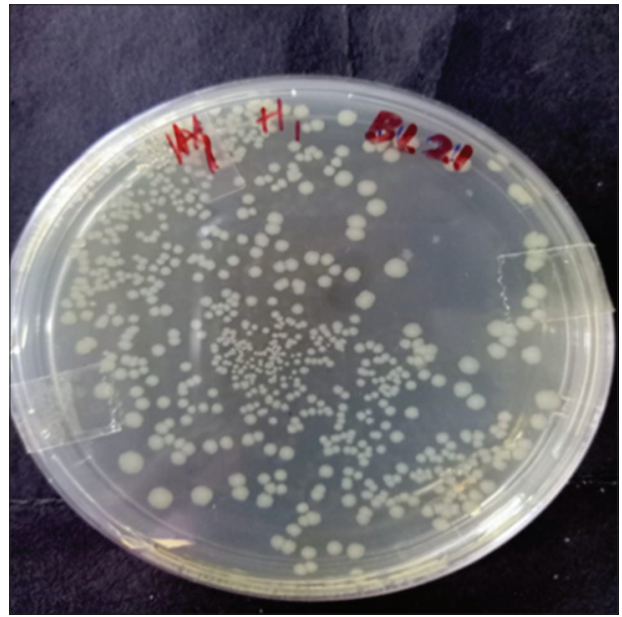

Figure-3: The culture of BL 21. The colony was assumed as recombinant Escherichia coli BL21 bacteria.

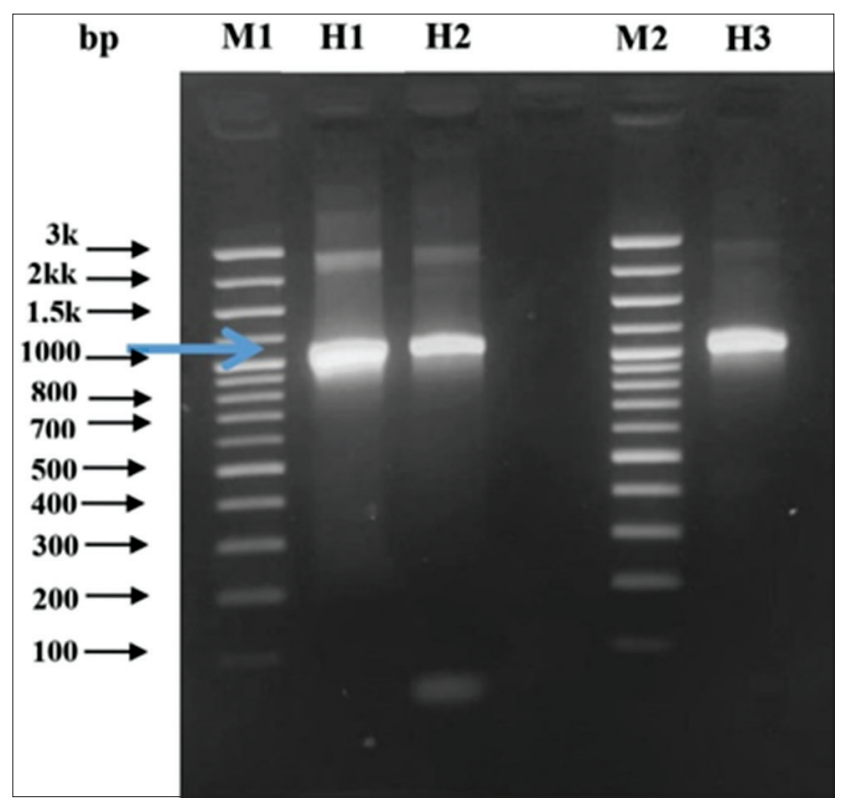

Figure-4: Recombinant plasmid DNA 1. DNA amplification results from GRA-4 gene of Toxoplasma in 1\% agarose gel. M1= Marker 100 bp, $\mathrm{H} 1=$ DNA in $5 \times$ dilution (Mix Go Tag); $\mathrm{H} 2=$ DNA in $10 \times$ dilution (Mix Go Tag); $\mathrm{M} 2=$ Marker $100 \mathrm{bp}$; H3=DNA Tachyzoite Toxoplasma (control). Arrow showed the recombinant plasmid DNA molecular weight.

inserted GRA-4 into the pPICZ $\alpha$ A expression vector alongside Picnic. The GRA-4 gene was also previously cloned into the pcDNA3 expression vector, which can express protein in $\mathrm{CHO}$ eukaryote cells. Using this GRA-4 expression system, a recombinant 


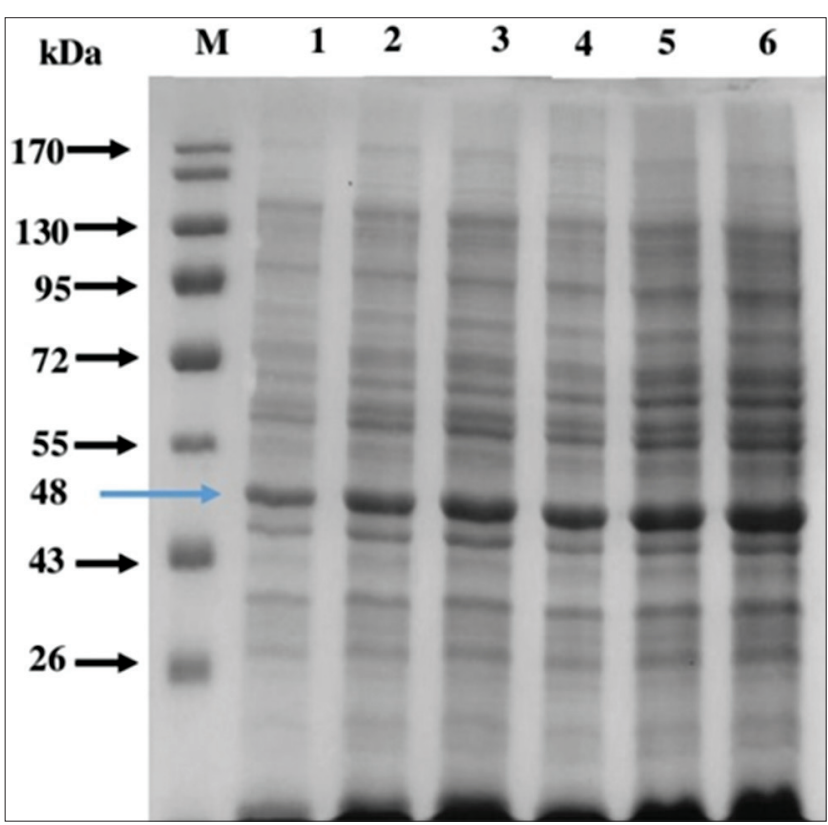

Figure-5: SDS PAGE electrophoresis of recombinant GRA-4 Toxoplasma gondii protein. M=Marker (Sigma); line $1=$ Supernatant protein (control); line $2=$ Supernatant $\mathrm{H} 1$; line $3=$ Supernatant $\mathrm{H} 2$; line $4=$ Pellet protein (control); line $5=$ Pelet $\mathrm{H} 1$; line $6=$ Pelet $\mathrm{H} 2$. Each $20 \mu \mathrm{L}$. Arrow showed the recombinant protein molecular weight.

vaccine has been produced and the ability of pGRA-4 to induce a protective immune response has been evaluated in model rats.

To produce a recombinant vaccine, T. gondii GRA-4 gene expression must be confirmed in eukaryotic cells (CHO). Successful GRA-4 gene cloning in the pcDNA3 expression plasmid was confirmed using a restriction enzyme and PCR. GRA-4 gene expression was further examined in vitro. Recombinant pcGRA-4 plasmid was transfected into $\mathrm{CHO}$ eukaryote cells using the calcium phosphate method and analyzed by SDS-PAGE. The molecular weight of the resulting protein was $42 \mathrm{kDa}$ on a Western blot. However, when the pET-32a expression vector was used for $G R A-4$ gene expression in a prokaryotic system, the reported molecular weight was approximately $50 \mathrm{kDa}$ [18]. Furthermore, the protein produced in this study was antigenic as it was recognized by human antibody positive serum from a patient with an acute toxoplasmosis infection.

Indrasanti et al. [19] reported the efficacy of rGRA-4 and rROP2 in inducing immunity in combination with alum. This data suggest that a multi-antigen $T$. gondii vaccine may be possible by utilizing alum as a supporting compound. This study also showed that the T. gondii MIC3 gene clone can successfully been cloned in E. coli.

Here, recombinant DNA transformation into DE3 bacteria (Figure-3) was performed using the heat shock technique, which transfers ligation product recombinant DNA into a competent host, DE3 [15]. Competent bacteria were obtained using cold $\mathrm{CaCl}_{2}$ treatment. Transformation was effectively performed at $42^{\circ} \mathrm{C}$ for $90 \mathrm{~s}[16,20]$. The transformation mechanism involving $\mathrm{CaCl}_{2}$ and heat was assumed to damage the bacterial cell wall, which eased the access of the plasmid into the bacteria [20].

The transformed cells were then cultured on an LB agar plate, which contained ampicillin as a selectable marker. The number of potential recombinant colonies was numerous; however, confirmation by Western blot is required. At the cellular level, gene expression of foreign DNA may have detrimental effects on the host, even if the translation product of the respective gene is not toxic. Foreign gene expression may be detrimental to recombinant bacteria in the form of reduction of cell growth and lowering cell stability compared to non-recombinant cells and may also cause morphological changes such as an increase in cell fragility $[21,22]$.

Recombinant plasmid analysis was conducted using the PCR method and the specific primers GRA-4 F and GRA-4 R, followed by agarose gel electrophoresis on a $1 \%$ agarose gel (Figure-4). The amplification result was positive for recombinant plasmid, which was shown by a similar band as a positive control.

An alignment of the amino acid sequence of the GRA-4 from the local isolate, which was cloned here, and the predicted GRA-4 obtained from GenBank showed $99.61 \%$ homology to predicted amino acid for the GRA-4 gene of the T. gondii Izatnagar isolate. The amino acid sequence predicted from the GRA-4 gene from the local isolate was different at positions 19 and 304. As compared to the predicted GRA-4 from all isolates observed in the NCBI databases, the predicted protein sequence of the GRA-4 from the local isolate coded for a different amino acid at position 326 (Asp to Ser substitution). Amino acid differences between the T. gondii GRA-4 gene from local isolate and the T. gondii $\mathrm{VEG}, T$. gondi $\mathrm{ME} 49$, and $T$. gondii cDNA clone XTG04280.2 were found at positions 28, 36, 39, $43,45,58,65,69,98,117,154,192,204,212,239$, 241 , and 276 . This result is similar to the study performed by Dewi [16], where the sequencing results of the MIC3 gene on pGEMT (used as the positive control in this study) was analyzed using the BLAST program. Alignment of the pWTA-M3 sequenced using the $\mathrm{pUC} / \mathrm{M} 13$ forward primer showed $97 \%$ homology with the MIC3 gene of the RH isolate from base 676 up to base 1164 . The sequence obtained by pUC/M13 reverse primer showed 98\% homology from $1387 \mathrm{bp}$ to $1833 \mathrm{bp}$.

Martin et al. [10] stated that the DNA vaccine vector which expressed the GRA-4 whole protein has been designed and used in immunization tests to compare the protective value of a vaccine by rGRA-4 which has been combined with alum. The authors also suggested that GRA-4 is a good candidate in vaccine development against toxoplasmosis.

Electrophoresis of GRA-4 recombinant protein using SDS PAGE (Figure-5) showed the protein recombinant with molecular weight of $48 \mathrm{kDa}$. This 
data differed from data observed by Ram et al. [23] and Meng et al. [24]. The difference in molecular weight is related to the histidine-tagged application [18]. The HEK293T eukaryotic cell was used for gene expression and found that the molecular weight was about $70 \mathrm{kDa}$, which was composed of $40 \mathrm{kDa}$ and $30 \mathrm{kDa}$ weights of GRA-4 gene expression and green fluorescent protein producer, respectively [24].

This study presented the preliminary data regarding the production of recombinant antigen GRA-4 of T. gondii, which showed the ability to be cloned into the pET SUMO plasmid. The sensitivity of GRA-4 cloning in pET SUMO plasmid will be tested in mice in future studies. The final target of our study is to develop the diagnostic kit for toxoplasmosis using the cloned GRA-4 in pET SUMO plasmid.

\section{Conclusion}

Here, we cloned the GRA-4 gene from a locally obtained T. gondii isolate into the pET SUMO plasmid. The amplification resulted in a $1036 \mathrm{bp} G R A-4$ gene fragment, which produced a $48 \mathrm{kDa}$ molecular weight after expression in DE3 competent cells.

\section{Authors' Contributions}

MH supervised the overall research work. TZH, AS, DP, and FF participated in sampling, made available relevant literatures, executed the experiment, and analyzed the cloning and expression of $T$. gondii GRA-4 recombinant protein. All authors interpreted the data, critically revised the manuscript for important intellectual contents, and approved the content.

\section{Acknowledgments}

The authors would like to thank Mrs. Arsiah from PAU UGM Yogyakarta for her kind assistance during the process of cloning and expression of T. gondii GRA-4 and sending the DNA sequencing. This study was supported by the Ministry of Research, Technology, and Higher Education of the Republic of Indonesia (No. 019/UN11.2/LT/SP3/2019).

\section{Competing Interests} interests.

The authors declare that they have no competing

\section{Publisher's Note}

Veterinary World remains neutral with regard to jurisdictional claims in published institutional affiliation.

\section{References}

1. Robert-Gangneux, F. and Darde, M.L. (2012) Epidemiology of and diagnostic strategies for toxoplasmosis. Clin. Microbiol. Rev., 25(2): 264-296.

2. Zhou, D.H., Zhao, F.R., Lu, P., Xia, H.Y., Xu, M.J., Yuan, L.G., Yan, C., Huang, S.Y., Li, S.J. and Zhu, X.Q. (2012) Seroprevalence of Toxoplasma gondii infection in dairy cattle in southern China. Parasit. Vectors, 5(1): 48-52.

3. Hanafiah, M., Nurcahyo, R.W., Siregar, R.Y., Prastowo, J., Hartati, S., Sutrisno, S. and Aliza, D. (2017) Detection of
Toxoplasma gondii in cat's internal organs by immunohistochemistry methods labeled with-[strept] avidin-biotin. Vet. World, 10(9): 1035-1039.

4. Hanafiah, M., Prastowo, P., Hartati, S., Aliza, D. and Nurcahyo, R.W. (2018) Detection of Toxoplasma gondii copro-prevalence by polymerase chain reaction using repetitive 529 bp gene in feces of pet cats (Felis catus) in Yogyakarta, Indonesia. Vet. World, 11(9): 338-1343.

5. Suwanti, L. T. (2015) The role of veterinarian in toxoplasmosis control through development of diagnostic kit and immunotherapy. Universitas Airlangga Surabaya. Printed by Airlangga University Press. pp.1-34.

6. Meng, M., Zhou, A., Lu, G., Wang, L., Zhao, G., Han, Y., Zhou, H., Cong, H., Zhao, Q., Zhu, XQ. and He, S. (2013) DNA prime and peptide boost immunization protocol encoding the Toxoplasma gondii GRA-4 induces strong protective immunity in BALB/c mice. BMC Infect. Dis., 13(1): 494-504.

7. Golkar, M., Shokrgozar, M.A., Rafati, S., Sodaie, M.R. and Assmar, M. (2005) Construction, expression and preliminary immunological evaluation of a DNA plasmid encoding the GRA2 protein of Toxoplasma gondii. Iran. Biomed. J., 9(1): 1-8

8. Cuppari, A.F., Sanchez, V., Ledesma, B., Frank, F.M., Goldman, A., Angel, S.O. and Martin, V. (2008) Toxoplasma gondii protease inhibitor-1 (TgPI-1) is a novel vaccine candidate against toxoplasmosis. Vaccine, 26(39): 5040-5045.

9. Sánchez, V.R., Pitkowski, M.N. and Cuppari, F.A.V. (2011) Combination of CPG-oligodeoxynucleotides with recombinant ROP2 or GRA4 proteins induces protective immunity against Toxoplasma gondii infection. Exp. Parasitol., 128(4): 448-453.

10. Sánchez, V.R., Fenoy, I.M., Picchio, M.S., Soto, A.S., Nadia, A., Goldman, A. and Martin, V. (2015) Homologous prime-boost strategy with TgPI-1 improves the immune response and protects highly susceptible mice against chronic Toxoplasma gondii infection. Acta Trop., 150: 159-165.

11. Invitrogen. (2002) BL21 Star ${ }^{\mathrm{TM}}$ (DE3) One Shot ${ }^{\mathbb{R}}$. Available from: https://assets.thermofisher.com/TFS-Assets/ LSG/manuals/oneshot_mach1_man.pdf. Retrieved on 23-09-2020.

12. Hanafiah, M., Helmi, T.Z., Amalia, Fihiruddin, and Bahi, M. (2020) Nucleotide plasmid and DNA Recombinant Sequence GRA-4 Toxoplasma gondii. The $2^{\text {nd }}$ International Conference on Veterinary, Animal, and Environmental Science (ICVAES 2020). FKH. Darussalam Banda Aceh. (In press).

13. Invitrogen (2010) Champion ${ }^{\mathrm{TM}}$ pET SUMO Protein Expression System, Manual part no. 25-0709. Life Technology. Available from: https://assets.thermofisher. com/TFS-Assets/LSG/manuals/petsumo_man.pdf. Retrieved on 25-09-2020.

14. Garcia- Réquet, N., Lebrun, M., Fourmaux, M., MercereauPuijalon, O., Taramann, Beckers, J.M., Samyn, B., Van Beeumen, J., Bout, D. and Dubremetz, J. (2000) The microneme protein MIC3 of Toxoplasma gondii is a secretory adhesin that binds to both the surface of the host cells and the surface of the parasite. Cell. Microbiol., 2(4): 353-364.

15. Sambrook, J. and Russell, D.W. (2001) Molecular Cloning: A Laboratory Manual. $3^{\text {rd }}$ ed. Cold Spring Harbour Laboratory Press, New York.

16. Dewi, N.N.D. (2006) Gene Cloning of the Micronema Protein 3 (MIC3) Local Isolate of Tachyzoite Toxoplasma gondii. Thesis. Biotechnology Studies Program Universitas Gadjah Mada, Yogyakarta.

17. McPherson, M.J. and Moller, S.G. (2006) PCR. $2^{\text {nd }}$ ed. Taylor and Francis Group, Madison Avenue, New York. p270.

18. Marjanh, A., Ghaffarifar, F., Forooghi, F., Dalimi, A.H., Sharifi, Z. and Maspi, N. (2018) Expression of plasmid 
encoded GRA-4 Gene of Toxoplasma gondii RH strain in CHO eukaryotic cells. Iran. J. Parasitol., 13(3): 392-398.

19. Indrasanti, D., Haryanto, A. and Artama, W.T. (2011) Subcloning and isolation of the micronema gene 3 (MIC-3) local isolate of Toxoplasma gondii. Molecule, 6(1): 10-18.

20. Glick, B.R. and Pasternak, J.J. (1994), Molecular Biotechnology. Principles and Applications of Recombinant DNA. ASM Press, Washington DC. p17-33.

21. Brown, T.A. (2010) Gene Cloning: An Introduction. Sixth. Edition. London: Chapman and Hall. p13-43.

22. Primrose, S.B., Twyman, R. and Old, R.W. (2002),
Principles of Gene Manipulation. $6^{\text {th }}$ ed. Wiley-Blackwell. p145-170.

23. Ram, H., Rao, J.R., Tewari, A.K., Banerjee, P.S. and Sharma, A.K. (2013) Molecular cloning, sequencing, and biological characterization of GRA-4 gene of Toxoplasma gondii. Parasitol. Res., 112(7): 2487-2494.

24. Martin, V., Supanitsky, A. and Echeverria, P.C. (2004) Recombinant GRA-4 or ROP2 protein combined with alum or the GRA-4 gene provides partial protection in chronic murine models of toxoplasmosis. Clin. Diagn. Lab. Immunol., 1(4): 704-710.

$* * * * * * * *$ 